\title{
Atrakcyjność dziedzin przemysłu w procesie rozwoju kraju i Mazowsza dawniej i dziś
}

\section{Andrzej Karpiński}

\section{STRESZCZENIE}

Niniejsze opracowanie przedstawia próbę odpowiedzi na 4 podstawowe pytania, a mianowicie:

1. Jakie działania zostały wykorzystane w pierwszym etapie procesu transformacji w polskim przemyśle w latach 1990-2014 w celu promowania jego rozwoju i czy zmiany w nich są obecnie wymagane?

2. Jakimi kryteriami należy kierować się przy wyborze najatrakcyjniejszych gałęzi przemysłu w celu zapewnienia najbardziej dynamicznego rozwoju przemysłowego kraju i czy kryteria te należy teraz skorygować w sytuacji globalnego kryzysu ekologicznego?

3. Jakie zmiany zaszły w najbardziej obiecujących branżach w procesie transformacji?

4. Jakie branże mogą być najbardziej atrakcyjne dla rozwoju miasta Warszawy i województwa mazowieckiego w przyszłości?

Głównym celem pracy jest pokazanie jak przejść od przemysłu, którego konkurencyjność opiera się na taniej sile roboczej, do nowego przemysłu, w którym innowacyjność i rozwój jego innowacyjnych sektorów będą odgrywały główną i decydującą rolę.

Słowa kluczowe: przemysł, rozwój, proces transformacji w przemyśle, atrakcyjne gałęzie przemysłu dla Warszawy i Mazowsza

\section{Wprowadzenie}

W toczących się obecnie dyskusjach o losach przemysłu w naszym kraju w przeszłości i jego perspektywach na przyszłość, co najmniej 4 obszary wymagają moim zdaniem znacznie większej uwagi i szerszej refleksji, łącznie z wyciągnięciem wniosków z naszych - nie zawsze tylko pozytywnych - doświadczeń.

Na plan pierwszy wysuwają się tu kolejno 4 sprawy, a za najpilniejsze uważam uzyskanie odpowiedzi na wynikające $\mathrm{z}$ nich następujące 4 pytania:

1. Jakie środki dla pobudzenia rozwoju, co nazywamy czasem ,, anatomią wzrostu czy rozwoju", zastosowano w przemyśle w Polsce w początkowym okresie jego transformacji w 25-leciu 1990-2014, czyli jakie czynniki ten rozwój spowodowały, napędzały i w decydującym stopniu się do niego przyczyniły oraz czy i jakich wymagają one obecnie zmian?

2. W przypadku, gdy państwo decyduje się na wsparcie rozwoju wybranych gałęzi i dziedzin przemysłu, rokujących największe szanse rozwojowe - jakie powinny być kryteria ich wyboru oraz czy wymagają one uzupełnień lub korekt? 
3. Jakim zmianom, w początkowym wymienionym wyżej okresie polskiej transformacji, uległa sytuacja w dziedzinach przemysłu uznanych u progu tego procesu w $1995 \mathrm{r}$. za te o największych szansach rozwojowych w naszych warunkach oraz jakie wnioski należy wyciągnąć z dotychczas zachodzących w nich przekształceń?

4. Jakie dziedziny przemysłu są obecnie i mogą być najbardziej atrakcyjne dla rozwoju na terenie Warszawy i województwa mazowieckiego?

W każdym z tych 4 obszarów pojawia się w ostatnim okresie wiele nowych uzupełnień do dotychczasowych diagnoz oraz propozycji, które wydaje się, zasługują na dyskusję.

\section{„Anatomia rozwoju” w 25-leciu transformacji}

Potrzeba i konieczność przerwania dominujących w pierwszej fazie transformacji w Polsce procesów deindustrializacji kraju, a następnie wejścia na drogę nowoczesnej reindustrializacji, nigdy nie były tak silne i odczuwalne jak obecnie. Decyduje o tym przyjęta dziś w Unii Europejskiej nowa długofalowa strategia jej rozwoju. Opiera się ona na założeniu, że „rozwój przemysłu szansą dla Europy”. Jest to całkowita zmiana stosunku do przemysłu. Poprzednio był on bliski poglądom, że przemysł staje się coraz bardziej schyłkowym sektorem w nowoczesnej gospodarce i będzie tracił na znaczeniu na rzecz usług. Istotną przyczyną zmiany tej orientacji był kryzys globalny z 2008 r., największy co do skali w okresie po II wojnie światowej. Równocześnie w obecnych warunkach zagrożeń ekologicznych na świecie rozwój może dotyczyć tylko tych dziedzin przemysłu, których ekspansja nie wywiera ujemnego i szkodliwego wpływu na stan przyrody, środowiska i klimatu. Rozwój ten, z samego założenia i w obliczu obecnych zagrożeń w gospodarce światowej, musi i powinien być znacznie bardziej selektywny niż dotychczas i nie może być pozostawiony tylko procesom żywiołowym.

W tej nowej sytuacji wymaga to szerszej i znacznie bardziej pogłębionej analizy mechanizmów, które wykorzystano do rozwoju przemysłu w okresie transformacji ustrojowej po 1989 r., czyli jaka była wspomniana wyżej anatomia tego rozwoju. Czasem nazywa się to także ",anatomią sukcesu". Jednak moim zdaniem, w tym konkretnym przypadku, byłby to termin nieco na wyrost w świetle tego, o czym będzie mowa dalej.

W dyskusjach na ten temat najczęściej pojawiało się pytanie: „Jak to było możliwe, że ogólna wielkość produkcji przemysłowej Polski po 25 latach od początku procesu jej transformacji, czyli w 2014 r., mogła osiągnąć rozmiary 2,6-krotnie większe niż w ostatnim roku Polski Ludowej, mimo likwidacji po 1989 r. około 1/3 potencjału przemysłowego, istniejącego w 1988 roku?"

Otóż głównym czynnikiem, który to umożliwił, było uruchomienie w tym okresie 2 nowych czynników napędowych tego rozwoju, których Polska Ludowa z przyczyn doktrynalnych wykorzystać nie mogła, a mianowicie:

- $\quad$ przejęcie przez kapitał zagraniczny części dawnych zakładów państwowych przez udział w ich prywatyzacji, czemu z reguły (choć nie zawsze) towarzyszyło zasadnicze 
rozszerzenie zasięgu ich działalności na znacznie większą skalę niż poprzednio w Polsce Ludowej; w wielu przypadkach bowiem oznaczało to przejście od ekspansji - tylko czy głównie na rynku krajowym - do ekspansji na rynku światowym,

- $\quad$ podjęcie nowych inwestycji w przemyśle prywatnym, a chociaż obejmowały one głównie zakłady małe i najmniejsze (tzw. „mikro”, czyli o zatrudnieniu do 10 osób), następowało to jednak w tak dużej skali, że dało odczuwalny i znaczny wzrost produkcji z tego tytułu.

Oba te nowe czynniki napędowe $\mathrm{z}$ nawiązką wypełniły lukę spowodowaną likwidacją 1/3 części majątku produkcyjnego w przemyśle państwowym (a licząc zatrudnieniem, czyli liczbą miejsc pracy oraz wielkością produkcji, ubytek ten był jeszcze większy).

Obecnie mamy już znacznie lepiej rozpoznany wpływ poszczególnych z tych czynników na wzrost produkcji całego przemysłu we wspomnianym okresie. A było to konieczne, gdyż właśnie w tych latach nastąpił wręcz skokowy wzrost udziału przedsiębiorstw, stanowiących własność zagraniczną. Ich udział w całej produkcji przemysłowej Polski wzrósł bowiem z 0,4\% w 1989 r. (a były to głównie firmy polonijne) do ponad 38\% w 2016 r. Oznaczało to już powstanie nowego przemysłu o zupełnie zmienionym charakterze.

Jeszcze większy był udział firm zagranicznych w samym przyroście produkcji w stosunku do jej poziomu wyjściowego w ostatnim roku Polski Ludowej. Można szacować, że przyrost produkcji w przedsiębiorstwach zagranicznych stanowił około 2/3 całego osiągniętego w tym okresie zwiększenia produkcji przemysłowej. A więc ich rola była wręcz decydująca.

Gdyby nie to - sam wzrost produkcji w przemyśle, stanowiącym własność kapitału krajowego (państwowego i prywatnego razem) wyniósłby w ciągu tych 25 lat nie więcej niż $70-80 \%$, tj. tylko o 1,8\% średniorocznie. Jak na tak długi okres, bo aż 25 lat, byłby to wzrost stosunkowo wolny, a w kraju tak opóźnionym w rozwoju przemysłowym jak Polska, oznaczałby niemal stagnację.

Wprawdzie w samym przemyśle prywatnym wzrost ten był o wiele wyższy, ale musiał on wypełnić lukę powstałą po spadku produkcji w wyniku likwidacji znacznej części przemysłu państwowego.

Gdyby więc można było uniknąć tak głębokiej likwidacji już istniejących zakładów, która była znacznie większa niż w innych krajach transformacji (z wyjątkiem byłej Niemieckiej Republiki Demokratycznej, w której jednak wstrzymanie produkcji w jednym zakładzie nie zawsze oznaczało jej likwidację w skali całego kraju, a często jedynie jej przeniesienie ze wschodnich do zachodnich Niemiec), to wzrost produkcji u nas byłby znacznie większy. Mogłaby ona zwiększyć się u nas 3,5-krotnie zamiast 2,6-krotnie, jak to miało miejsce w tym okresie. A miałoby to niezwykle korzystny wpływ na poziom dochodów budżetowych państwa i jego równowagę finansową oraz sytuację na rynku pracy. Ze względu na wyjątkowo u nas wysoki poziom bezrobocia w latach 90., które osiągnęło skalę masową w tym okresie, mogło to mieć ogromne znaczenie.

Równocześnie nie można jednak nie dostrzegać, że osiągnięty u nas wówczas wzrost produkcji w bardzo dużym stopniu opierał się na zastąpieniu produkcji finalnej (czyli obejmującej cały cykl od surowca aż do wyrobu gotowego już do bezpośredniej konsumpcji) 
montażem wyrobów gotowych z elementów w całości importowanych. A to jest o wiele łatwiejsze niż rozwój produkcji finalnej. Pozwala bowiem ominąć całą fazę projektowania i wprowadzania do produkcji nowych wyrobów. Zmniejszenie udziału produkcji finalnej w całej produkcji oznaczało cofnięcie się do niższej fazy całego cyklu produkcyjnego, co prof. K. Marczewski nazwał „uwstecznieniem struktury”, a rezultatem tego był głęboki regres $\mathrm{w}$ poziomie uprzemysłowienia kraju.

Dyskusja na ten temat doprowadziła do ujawnienia zjawiska, które zyskało u nas nazwę „polskiego paradoksu przemysłowego". Wynika on z faktu, że Polska pod względem przeciętnego rocznego tempa wzrostu produkcji („Average Annual Growth Rate”, czyli w skrócie AAGR) znalazła się na jednym z 5 pierwszych miejsc wśród krajów Unii Europejskiej, ale równocześnie pod względem innowacyjności i tempa modernizacji swej struktury przemysłowej, co mieć będzie decydujące znaczenie dla przyszłych losów przemysłu w naszym kraju, zajęła dopiero jedno z ostatnich 5 miejsc na 28 krajów Unii. Tak zasadnicza rozbieżność wykazuje więc wszystkie cechy paradoksu, który powinien dawać dużo do myślenia. Zwrócenie uwagi na ten problem niewątpliwie stanowi nowy element w dotychczasowych ocenach wyników opisywanego 25-lecia.

Nie trudno też dostrzec, że rezerwy uruchomione tą droga, a więc prywatyzacją zakładów państwowych i powstawaniem nowych zakładów prywatnych, będą się stopniowo wyczerpywać. A w tej sytuacji konieczne jest uruchomienie nowych czynników, które mogłyby spełnić rolę nowego napędu i pobudzić proces rozwoju w przyszłości.

Na pierwszy plan wysuwa się tu przede wszystkim innowacyjność i tworzenie nowego przemysłu, który swą konkurencyjność w stosunku do innych partnerów na rynku będzie opierać na innowacyjności swojej produkcji, a nie jak dotychczas na konkurowaniu głównie tanią pracą. W tym przemyśle przyszłości główną rolę będą odgrywały branże, w których procesy innowacyjne mają decydujące znaczenie, czyli związane z wysoką techniką. W tej sytuacji nie wolno oceniać wyników przemysłu wyłącznie na podstawie osiąganego przez niego średniego rocznego tempa wzrostu produkcji czy PKB. Posługiwanie się u nas w propagandzie głównie tym wskaźnikiem było wielkim błędem popełnianym przez wszystkie kolejne rządy w Polsce.

Obecnie wielokrotnie ważniejszym wskaźnikiem, który będzie powszechnie stosowany w przyszłości, jest rola wyrobów innowacyjnych w całej produkcji przemysłowej kraju oraz udział branż, w których procesy innowacyjne nabierają decydującego znaczenia dla rozwoju. Do nich na pewno zaliczyć należy elektronikę i przemysł farmaceutyczny. Ale statystyka światowa stawia dopiero pierwsze kroki w metodach konstrukcji tych wskaźników i ocenie ich udziału, chociaż postęp w tej dziedzinie będzie miał największe znaczenie.

\footnotetext{
${ }^{1}$ Gospodarka polska 1990-1992, L. Zienkowski (red.), Zakład Badań Statystycznych GUS i PAN, Warszawa 1992 r., s. 120.
} 


\section{Kryteria wyboru dziedzin przemysłu, stwarzających największe szanse rozwojowe}

Drugi obszar, wymagający szerszej i bardziej pogłębionej analizy oraz lepszego upowszechnienia wiedzy na ten temat, zwłaszcza wśród polityków, stanowią kryteria, jakimi powinno kierować się państwo, jeżeli decyduje się na wsparcie rozwoju niektórych wybranych branż przemysłu, rokujących największe szanse na przyszłość. Dokonanie ich wyboru wymaga rozpoznania wpływu rozwoju poszczególnych branż na rozwój całego przemysłu, czyli traktowania ich jako części składowych całego przemysłu jako systemu. To zaś jest typowym podejściem makro, a nie mikro, a więc z punktu widzenia poszczególnych przedsiębiorstw czy sektorów biznesu w przemyśle. Już bowiem od czasu Rooseveltowskiego „New Dealu" i Doliny Krzemowej w USA oraz wdrażania teorii Keynesa w Europie w latach 30. ubiegłego wieku, niekwestionowany jest dziś pogląd, że państwo może aktywnie i skutecznie wpływać na realne procesy rozwoju w przemyśle i gospodarce, również w warunkach gospodarki rynkowej, chociaż wpływ ten może być zarówno pozytywny jak i negatywny.

Jeżeli za główny pozytywny potencjalny efekt uznamy możliwość przyspieszenia tą drogą rozwoju całego przemysłu i gospodarki, to podstawowym tego warunkiem jest zdolność do trafnego rozpoznania i wybór tych branż przemysłu lub dziedzin jego produkcji, które są zdolne w największym stopniu zdynamizować rozwój przemysłu jako całości. Działania państwa zmierzające w tym kierunku określa się czasem jako „dokonywanie wyboru wygranych i przegranych” (a w terminologii angielskiej "picking winners and losers”). Praktyka taka jest ostro krytykowana przez ortodoksyjnych neoliberałów ekonomicznych. W przypadku jednak trafnego rozpoznania tych branż daje to tak wielkie efekty, że szeroko stosuje się te praktyki nawet w krajach o skrajnie neoliberalnej doktrynie jak USA. Dlatego w XX w., zwłaszcza od czasu J. Schumpetera, problem kryteriów tego wyboru stanął w centrum dyskusji wśród ekonomistów i przemysłowców.

W krajach o gospodarce rynkowej kryterium to upatrywano najczęściej w 3 wskaźnikach typowo rynkowych, takich jak:

- $\quad$ osiąganie przez daną branżę najwyższego zysku lub jego najkorzystniejszej relacji do zaangażowanego kapitału, czyli rentowność,

- silna pozycja konkurencyjna w sprzedaży na rynku,

- Szansa na wykorzystanie luk i nisz rynkowych.

Słabością powyższych kryteriów jest jednak fakt, że zmiany pod tym względem, czasem nawet bardzo głębokie, zachodzą niezwykle szybko. Stąd zawodzą one jako kryterium wyborów bardziej długookresowych. A z drugiej strony, o tym gdzie można osiągnąć największe zyski, znacznie więcej wiedzą i mają lepsze rozeznanie tych możliwości przemysłowcy i biznesmeni niż pracownicy nauki czy funkcjonariusze administracji przemysłowej państwa. Nie wydaje się więc celowe zastępowanie ich w tych funkcjach.

W tych warunkach brytyjski ekonomista Artur Pigou wprowadził na przełomie XIX i XX w. nowe pojęcie, które nazwano „efektami zewnętrznymi” (w terminologii angielskiej: „externalities") $)^{2}$. Rozumie się przez to efekt, jaki daje zastosowanie wyrobów danej branży

\footnotetext{
2 „The Economist” z 19 sierpnia 2017 r., s. 54.
} 
lub tworzonej w niej technologii u ich użytkowników, czyli w podmiotach poza jednostka, która je wyprodukowała. Stąd A. Pigou uważa się za twórcę zastosowania tej kategorii w ekonomii.

Odróżnia się przy tym wyraźnie efekty zewnętrzne, korzystne dla gospodarki jako całości („,positive externalities”) od efektów o skutkach ujemnych („,negative externalities”), a także takie, które powodują rozwój niektórych branż. Te ostatnie dotyczą najczęściej skutków społecznych i ekologicznych, których rozpoznanie, a tym bardziej im przeciwdziałanie, wykracza daleko poza możliwości korporacji przemysłowych czy biznesu. Ten efekt zewnętrzny mierzy się zazwyczaj zasięgiem upowszechnienia u użytkownika nowych technologii oraz bardziej sprawnych rozwiązań ekonomicznych i technicznych. A to z reguły nie znajduje wyrazu w zysku i miernikach finansowych u producenta. Dlatego uwzględnia się dodatkowo wpływ poszczególnych branż, jaki ich rozwój wywiera na ogólny wynik ekonomiczny całego przemysłu, mierzony poprawą wskaźników makroekonomicznych takich jak: kapitałochłonność, materiałochłonność, energochłonność, pracochłonność, importochłonność liczonych na jednostkę wartości produkcji.

Również u nas podjęto ten problem. W 1982 r., a więc już w Polsce Ludowej, powołano Międzyresortowy Zespół Rządowy dla przebudowy i modernizacji struktury przemysłu krajowego. Wspomniany Zespół zaproponował bardzo nowatorskie jak na ówczesne czasy rozwiązania. Można je ująć w 3 zasadniczych ustaleniach:

- Zaproponował, aby za kryterium to uznać u nas „efekt zewnętrzny”, czyli kategorię „externalities”, co wtedy odbiegało od tendencji dominujących w innych krajach, a dopiero później zyskało w nich szerszych zwolenników. Można więc powiedzieć, że pod tym względem wyprzedziliśmy inne kraje, przynajmniej w ramach ówczesnej Rady Wzajemnej Pomocy Gospodarczej (RWPG).

- Druga propozycja była jeszcze bardziej radykalna, bo uznano, że ewentualne priorytety sektorowe i wynikające stąd przywileje dla selektywnie wybranych branż powinny być stosowane tylko i wyłącznie w stosunku do tych z nich, których wyroby zastosowane u ich użytkowników dają znaczące „efekty zewnętrzne” i to w dużej skali. Nazywano je u nas czasem „przemysłami wysokiej szansy”. Występują one najczęściej w branżach rozpowszechniających w gospodarce nowoczesne technologie, które wnoszą jakościowe zmiany, a stąd nazywane są one „technologiami przełomu” (w terminologii angielskiej„break-through-technologies”). A takie technologie w okresie początkowym wymagają z reguły ochrony na rynku. Jeszcze bardziej radykalnym rozwiązaniem było uznanie, że stosowanie tych priorytetów sektorowych ma sens ekonomiczny tylko wtedy, gdy efekty zewnętrzne spowodowane zastosowaniem priorytetów sektorowych znacznie przewyższają nakłady państwa lub samorządu, jakie trzeba ponieść, aby uruchomić ich promocję. Konsekwentne przestrzeganie tej zasady oznaczałoby wręcz rezygnację ze stosowania priorytetów w przypadku nawet tych branż i dziedzin, które mają duże znaczenie społeczne i gospodarcze w danej gospodarce, ale ich rozwój nie generuje żadnych efektów zewnętrznych. 
- Trzecim elementem ówczesnego dorobku było zaproponowanie mierników, jakie powinny być stosowane do pomiaru efektów zewnętrznych, przy przyjęciu tego kryterium. To z kolei - dzięki ich przyjęciu pozwoliło ustalić wielkość efektów zewnętrznych, jakie powoduje rozwój poszczególnych branż i dziedzin produkcji. A co jeszcze ważniejsze, ocenić na tej podstawie, w których te efekty zewnętrzne są największe i najbardziej pobudzają rozwój całego przemysłu i gospodarki. Stworzyło to punkt wyjścia do rozpoznania, które dziedziny przemysłu - ze względu na specyfikę naszych warunków naturalnych, ich korzystne ukształtowanie oraz dorobek i tradycje z przeszłości - moga odegrać szczególną rolę w naszym rozwoju przemysłowym i zapewnić nam największą konkurencyjność w stosunku do innych partnerów na rynku, a więc stać się naszą specjalnością narodową („National lub Local Championship”). To zaś stwarza możliwości rozpoznania możliwych głównych kierunków specjalizacji danego przemysłu pod kątem konkurencji na rynkach zagranicznych („National lub Local Champions”), a na tej podstawie opracowania programu specjalizacji i jego głównych kierunków.

Zespół ten wypowiedział się wstępnie, ale jednoznacznie, za specjalizacją przemysłu w Polsce w rozwoju następujących 7 gałęzi. Były to: przemysł farmaceutyczny, kosmetyczny, taboru kolejowego i środków transportu zbiorowego, stoczniowy, wyposażenia dla elektrowni, celulozowo-papierniczy i zbrojeniowy. Z wyjątkiem przemysłu stoczniowego wszystkie te branże znalazły się później w grupie dziedzin zaliczonych do obszaru wysokiej szansy w badaniach, o których będzie mowa w następnym rozdziale.

Propozycje te wywołały jednak głębokie kontrowersje. Zagrażały bowiem preferowanym dotychczas tradycyjnym gałęziom przemysłu (górnictwo węglowe, hutnictwo i przemysł maszynowy). A w tych warunkach spotkały się z głębokim sprzeciwem ze strony kompleksu przemysłu ciężkiego, który odgrywał wtedy w naszym przemyśle kluczową rolę i był wyjątkowo silnie reprezentowany we władzach politycznych (Śląsk i Wybrzeże). W rezultacie propozycje te zostały w całości odrzucone.

Inicjatywę tę podjęto ponownie dopiero po zmianie ustroju w 1989 r., ale jeszcze niemal u progu procesu transformacji, bo w 1995 r. Z inicjatywą w tej sprawie wystąpiło Polskie Towarzystwo Ekonomiczne (PTE), a więc organizacja społeczna, a nie rząd i państwo. W tym okresie całkowicie dominowała już jednak u nas doktryna neoliberalizmu ekonomicznego w jej najbardziej skrajnej wersji, a doktrynerstwo w jej stosowaniu wystąpiło w Polsce na znacznie większą nawet skalę niż w innych krajach transformacji ustrojowej. Dlatego prof. G. Kołodko słusznie nazwał to „nadwiślańskim neoliberalizmem”3, gdyż szereg niekorzystnych jego cech określa jego specyfikę. W tym klimacie ówczesny rząd ponownie całkowicie odrzucił tę koncepcję, chociaż proponowane w jej ramach kryteria mogłyby mieć dużą przydatność dla praktyki przemysłowej. Dostarczałyby bowiem decydentom zarówno na poziomie centralnym, jak i w województwach, jasnych kryteriów, opartych na podstawach naukowych - do oceny żądań poszczególnych gałęzi przemysłu, aby zapewnić im najwyższy priorytet w dostępie do środków inwestycyjnych. A równocześnie umożliwiałyby prze-

\footnotetext{
${ }^{3}$ G. Kołodko, Jak uzdrowić Polske, Tygodnik „Przegląd” z 19 października 2015 r., s. 9.
} 
ciwstawienie się tym tendencjom w przypadku, gdy wykorzystywano w tym celu naciski polityczne, co przed 1989 r. było zjawiskiem powszechnym. Z drugiej zaś strony ograniczałoby pole tego wyboru przez wyeliminowanie „a limine” gałęzi, które tych kryteriów nie spełniają. Niestety szansy tej nie wykorzystano.

\section{Losy dziedzin przemysłu, uznanych w 1995 r. za obszary wysokiej szansy po 20 latach transformacji}

Trzecim obszarem, który wymaga moim zdaniem znacznie większej uwagi i pogłębionej, krytycznej analizy, zarówno w skali całego przemysłu jak i w każdym województwie, a także w miastach o poważniejszym potencjale przemysłowym, jest analiza zmian sytuacji w dziedzinach przemysłu uznanych u progu transformacji za "przemysły wysokiej szansy”.

W tym świetle trzeba przypomnieć, że w 1995 r., czyli zaraz po powrocie do poprzednio osiąganego poziomu w przemyśle, a więc po wyrównaniu spadku produkcji w latach 1990-1994 w początkach transformacji o 24\%, powstała konieczność dokonania wyboru drogi dalszego rozwoju.

W tym celu, w świetle kryteriów przedstawionych w rozdziale 2 niniejszego opracowania, podjęto próbę zidentyfikowania dziedzin przemysłu, rokujących największą szansę do rozwoju w konkretnych warunkach naszego kraju. Dziedziny przemysłu, które w wyniku przeprowadzonych analiz znalazły się na pierwszych 15 miejscach rankingu, w świetle tych kryteriów, przestawia tabela 1 . 
Tabela 1. Najbardziej atrakcyjne branże przemysłu do rozwoju, w warunkach polskich, w świetle badań dla $1995 \mathrm{r}$.

\begin{tabular}{|c|c|c|c|c|c|c|}
\hline \multirow[b]{2}{*}{ 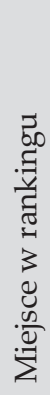 } & \multirow{2}{*}{ 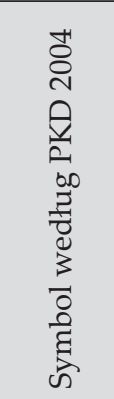 } & \multirow{2}{*}{ 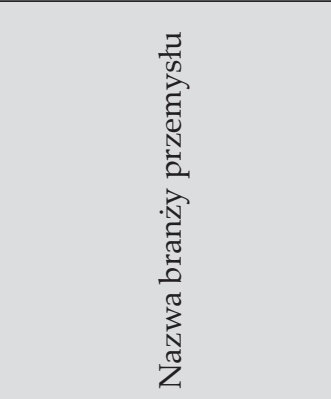 } & \multirow[b]{2}{*}{ 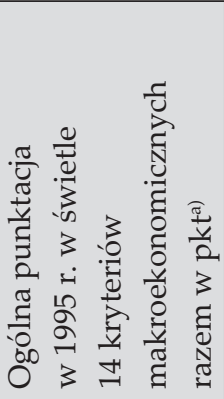 } & \multirow[b]{2}{*}{ 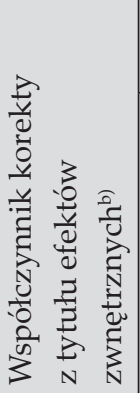 } & \multicolumn{2}{|c|}{$\begin{array}{l}\text { Udział w całej produkcji } \\
\text { przemysłowej w \% }\end{array}$} \\
\hline & & & & & $\begin{array}{l}\dot{1} \\
\text { ळे } \\
\text { ने }\end{array}$ & $\stackrel{\dot{1}}{\stackrel{2}{\sigma}}$ \\
\hline 1 & 2 & 3 & 4 & 5 & 6 & 7 \\
\hline$x$ & $\mathrm{C}+\mathrm{D}+\mathrm{E}$ & PRZEMYSŁ OGÓŁEM & $x$ & $x$ & 100,0 & 100,0 \\
\hline & & $\begin{array}{l}\text { w tym: } 15 \text { gałęzi } \\
\text { wysokiej szansy } \\
\text { wymienionych niżej } \\
\text { razem }\end{array}$ & $x$ & & 8,5 & 9,4 \\
\hline 1. & 35.3 & $\begin{array}{l}\text { z tego: } \\
\text { - lotniczy }\end{array}$ & 254 & 0,70 & 0,4 & 0,3 \\
\hline 2. & 31.5 & $\begin{array}{l}\text { - sprzętu } \\
\text { oświetleniowego }\end{array}$ & 250 & 0,80 & 0,6 & 0,3 \\
\hline 3. & 24.4 & - farmaceutyczny & 248 & 0,65 & 0,8 & 1,1 \\
\hline 4. & 33.1 & - aparatury medycznej & 244 & 0,90 & 0,1 & 0,1 \\
\hline 5. & 31.2 & $\begin{array}{l}\text { - aparatury } \\
\text { rozdzielczej } \\
\text { i zabezpieczeniowej }\end{array}$ & 239 & 0,80 & 0,3 & 0,4 \\
\hline 6. & 29.11 & $\begin{array}{l}\text { - turbin i wyposażenia } \\
\text { elektrowni }\end{array}$ & 237 & 0,85 & 0,2 & 0,5 \\
\hline 7. & 32.2 & $\begin{array}{l}\text { - sprzętu } \\
\text { telekomunikacyjnego }\end{array}$ & 230 & 0,95 & 0,3 & 0,3 \\
\hline 8. & 33.2 & $\begin{array}{l}\text { - aparatury } \\
\text { pomiarowej }\end{array}$ & 228 & 0,90 & 0,4 & 0,3 \\
\hline 9. & 30.02 & - komputerowy & 228 & 1,00 & 0,01 & 0,02 \\
\hline 10. & 33.4 & $\begin{array}{l}\text { - sprzętu } \\
\text { fotograficznego } \\
\text { i optycznego }\end{array}$ & 228 & 0,90 & 0,1 & 0,0 \\
\hline 11. & 32.1 & $\begin{array}{l}\text { - elektroniki } \\
\text { profesjonalnej }\end{array}$ & 221 & 0,95 & 1,1 & 1,0 \\
\hline
\end{tabular}




\begin{tabular}{|c|c|c|c|c|c|c|}
\hline \multirow[b]{2}{*}{ 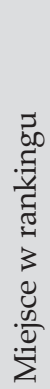 } & \multirow{2}{*}{ 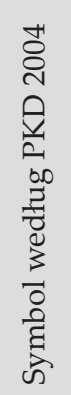 } & \multirow{2}{*}{ 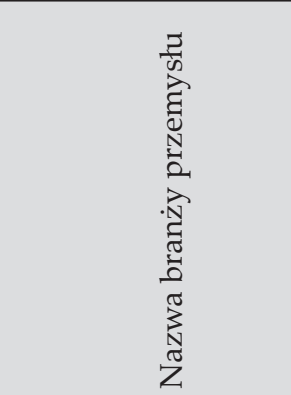 } & \multirow[b]{2}{*}{ 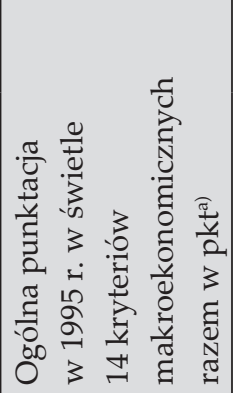 } & \multirow[b]{2}{*}{ 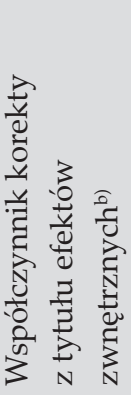 } & \multicolumn{2}{|c|}{$\begin{array}{l}\text { Udział w całej produkcji } \\
\text { przemysłowej w \% }\end{array}$} \\
\hline & & & & & $\stackrel{\dot{1}}{\circ}$ & 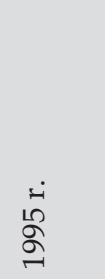 \\
\hline 12. & 25.2 & $\begin{array}{l}\text { - kosmetyczny } \\
\text { i wyrobów } \\
\text { toaletowych }\end{array}$ & 219 & 0,65 & 0,7 & 0,4 \\
\hline 13. & 22.1 & - celulozy i papieru & 206 & 0,40 & 1,0 & 1,3 \\
\hline 14. & 24.3 & - farb i lakierów & 206 & 0,65 & 0,5 & 0,4 \\
\hline 15. & 34.1 & - samochodowy & 205 & 0,70 & 2,0 & 3,0 \\
\hline
\end{tabular}

a) Założenia metodyczne i wyniki dla wszystkich branż przedstawia praca: A. Karpiński, Prawda i kłamstwa o przemyśle, Fundacja Oratio Recta, Warszawa 2018, s. 289-291.

b) Wynik oceny w świetle kryteriów makroekonomicznych (kolumna 4) korygowany był tym wskaźnikiem, który mówi o wielkości „efektów zewnętrznych" („externalities”) powodowanych przez rozwój danej branży, przyjmując za 1 najwyższą wielkość tych efektów stwierdzonych w przypadku rozwoju przemysłu komputerowego.

Im wyższa jest w tej tabeli ogólna punktacja poszczególnej z tych branż w stosunku do średniego poziomu dla całego przemysłu przyjętego za 100, tym bardziej rozwój danej branży przyczynia się do poprawy wyników makroekonomicznych i efektywnościowych dla całego przemysłu.

Z kolei współczynnik korekty w kolumnie 5. tabeli 1. mówi o ocenianej wówczas wielkości efektów zewnętrznych („externalities”), powodowanych przez rozwój danej branży. Szacunki te w opisywanym okresie objęły analizą jedynie poziom działów przemysłu, a więc tych oznaczonych symbolami dwucyfrowymi w polskiej klasyfikacji przemysłowej. Lepsze wyniki dałaby analiza na niższym poziomie. Tak więc szacunki te, jak dotychczas, mają charakter tylko wielkości przybliżonych i orientacyjnych.

Mimo to, rozpoznanie tych dziedzin przemysłu pozwoliło postawić jeszcze ważniejsze pytanie i podjać próbę na nie odpowiedzi, a mianowicie: „Jakie były losy tych branż przemysłu uznanych za „przemysły największej szansy” w świetle badania dla roku 1995 r. w ciągu następnych 20 lat transformacji w przemyśle w Polsce?" Odpowiedź na to pytanie zawiera tabela 2, z której wynikają co najmniej 3 podstawowe stwierdzenia. 
Tabela 2. Losy dziedzin przemysłu, uznanych w badaniu z 1995 r. za dziedziny wysokiej szansy, w okresie transformacji po $1989 \mathrm{r}$.

\begin{tabular}{|c|c|c|c|c|c|c|c|}
\hline \multirow[b]{2}{*}{ 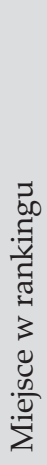 } & \multirow[b]{2}{*}{ 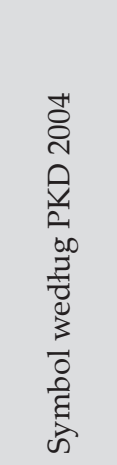 } & \multirow[b]{2}{*}{ 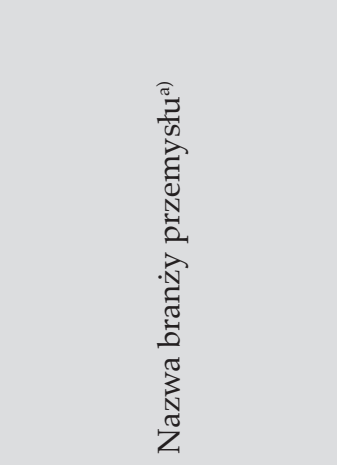 } & \multirow[b]{2}{*}{ 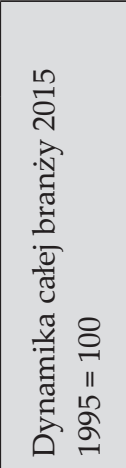 } & \multicolumn{4}{|c|}{$\begin{array}{l}\text { Część potencjału przemysłowego } \\
\text { istniejącego w } 1988 \text { r. objęta w \%: }\end{array}$} \\
\hline & & & & 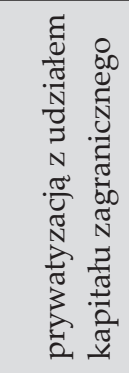 & 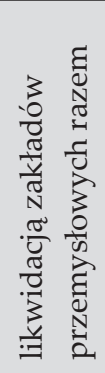 & 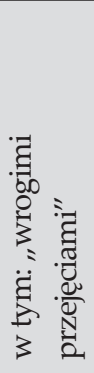 & 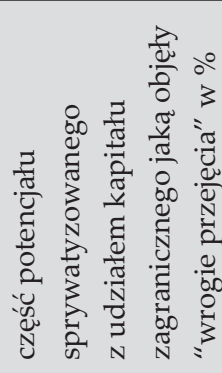 \\
\hline 1 & 2 & 3 & 4 & 5 & 6 & 7 & 8 \\
\hline \multirow[t]{2}{*}{$x$} & $\mathrm{C}+\mathrm{D}+\mathrm{E}$ & PRZEMYSŁ OGÓŁEM & 270 & 20 & 33 & 5 & 25 \\
\hline & & $\begin{array}{l}\text { w tym: } 15 \text { gałęzi } \\
\text { wysokiej szansy } \\
\text { wymienionych razem }\end{array}$ & 289 & 64 & 45 & 23 & 37 \\
\hline 1. & 35.3 & z tego: - lotniczy & 180 & 74 & 20 & 14 & 19 \\
\hline 2. & 31.5 & $\begin{array}{l}\text { - sprzętu } \\
\text { oświetleniowego }\end{array}$ & 600 & 69 & 74 & 59 & 86 \\
\hline 3. & 24.4 & - farmaceutyczny & 235 & 42 & 4 & - & - \\
\hline 4. & 33.1 & - aparatury medycznej & 410 & 6 & 29 & - & - \\
\hline 5. & 31.2 & $\begin{array}{l}\text { - aparatury } \\
\text { rozdzielczej } \\
\text { i zabezpieczeniowej }\end{array}$ & 485 & - & 74 & - & - \\
\hline 6. & 39.11 & $\begin{array}{l}\text { - turbin i wyposażenia } \\
\text { elektrowni }\end{array}$ & 85 & 71 & 72 & 45 & 63 \\
\hline 7. & 32.2 & $\begin{array}{l}\text { - sprzętu telekomuni- } \\
\text { kacyjnego }\end{array}$ & 245 & 93 & 97 & 92 & 100 \\
\hline 8. & 33.2 & $\begin{array}{l}\text { - aparatury } \\
\text { pomiarowej }\end{array}$ & 120 & - & 3 & - & - \\
\hline 9. & 30.02 & - komputerowy & 11-razy & 24 & 83 & 24 & 100 \\
\hline 10. & 33.4 & $\begin{array}{l}\text { - sprzętu } \\
\text { fotograficznego } \\
\text { i optycznego }\end{array}$ & 525 & - & 64 & - & - \\
\hline
\end{tabular}

a) Nazwy uproszczone.

b) Liczona wartością majątku produkcyjnego w przemyśle.

Uwaga: dane niepełne i tylko szacunkowe z powodu braku precyzyjnej informacji, zwłaszcza dane o udziale kapitału zagranicznego w całym potencjale przemysłowym poszczególnych branż z konieczności są tylko orientacyjne i przybliżone. Decyduje o tym wyjątkowa trudność uzyskania do nich dostępu, a nawet czasem dążenie do ukrywania rzeczywistego stanu wielkości. Stąd wynika możliwość błędów w tych danych, z czym trzeba się liczyć 
1. Wspomniane 20 lat transformacji wyraźnie potwierdzało zdolność branż przemysłu, zaliczonych do tej grupy na progu tego 20-lecia do zdynamizowania rozwoju przemysłu jako całości. O ile cała produkcja przemysłowa wzrosła w omawianym 20-leciu (1996-2015) 2,7-krotnie, to w 15 dziedzinach zaliczonych do „przemysłów największej szansy" łącznie wzrosła ona 3,8-krotnie, a więc o połowę szybciej niż w całym przemyśle. A jeżeli uwzględnić dodatkowo także małe zakłady w tych dziedzinach (o zatrudnieniu do 49 osób), to łączny wzrost ich produkcji był ponad 4-krotny. W tej grupie wyraźnie dominowały branże przemysłu o szybszej dynamice rozwoju niż w przemyśle ogółem. Aż w 9 z nich na 15 zaliczonych do tej grupy, czyli w 2/3 tych branż, ich dynamika wzrostu produkcji wyprzedzała tempo wzrostu całej produkcji przemysłowej. Najszybciej wśród nich rozwijały się w tym okresie następujące dziedziny przemysłu uszeregowane kolejno metodą rankingu: przemysł komputerowy (wzrost 11-krotny i to mimo likwidacji największych fabryk w tym przemyśle), kosmetyczny (9-krotny), samochodowy (łącznie z produkcją części zamiennych - 8-krotny), sprzętu oświetleniowego (6-krotny), sprzętu fotograficznego i optycznego (głównie przyrządy laserowe - 5-krotny), elektrycznej aparatury rozdzielczej (prawie 5-krotny), aparatury medycznej (4-krotny), celulozy i papieru (prawie 3-krotny) oraz elektroniki profesjonalnej (również prawie 3-krotny).

Wzrost ten byłby jeszcze wyższy gdyby nie to, że szereg branż przemysłowych $\mathrm{z}$ tej grupy rozwijało swą produkcję $\mathrm{u}$ nas wolniej niż w całym przemyśle, podczas gdy $w$ innych krajach $w$ tym samym okresie ich tempo wyprzedzało znacznie wzrost całej produkcji przemysłowej. $\mathrm{W}$ tej grupie znalazły się $\mathrm{u}$ nas takie dziedziny przemysłu jak: farmaceutyczny (wzrost 2,3-krotny), lotniczy (1,8-krotny), farb i lakierów (1,5-krotny) oraz aparatury pomiarowej (1,2-krotny).

Wolniejszy $u$ nas wzrost produkcji w tych dziedzinach przemysłu niż w przemyśle ogółem wynikał głównie z 2 przyczyn, a mianowicie:

- $\quad$ z likwidacji głównych zakładów w 2 branżach (przemysł budowy maszyn dla elektrowni oraz przemysł aparaturowy),

- $\quad$ znacznie szybszego, w niektórych z tych branż, wzrostu importu wyrobów wytwarzanych w tych gałęziach niż ich produkcji w kraju. Dotyczyło to 5 branż przemysłu z wymienionej wyżej 15, a mianowicie: lotniczego, farmaceutycznego, aparatury pomiarowej, farb i lakierów oraz komputerowego, co było jednak uzasadnione w tym przypadku.

Jest charakterystyczne, że import wyrobów tych branż wzrósł 3-krotnie szybciej od ich produkcji w kraju. W rezultacie sprzedaż ich wyrobów na rynku wewnętrznym (łącznie z importem) wzrosła ogółem znacznie szybciej niż cała sprzedaż wyrobów przemysłowych w naszym kraju. Tylko korzyści z tego odnieśli eksporterzy określonych wyrobów na nasz rynek, a nie ich producenci w kraju.

Jak z powyższego wynika, wolniejszego u nas wzrostu produkcji w tych branżach przemysłu niż przemysłu ogółem nie można wytłumaczyć jakimiś przyczynami obiektywnymi. Nie było to więc nieuniknione. Zadecydowały o tym 
niekorzystne dla nas wyniki gry rynkowej. A to spowodowało, że potencjalnie istniejące możliwości w tych obszarach nie zostały wykorzystanie.

Rzeczywiste wyniki potwierdziły zdolność także tych dziedzin przemysłu do zdynamizowania całego przemysłu i gospodarki. Wskazuje to zarazem, że wybór owych 15 dziedzin przemysłu i zaliczenie ich do grupy dziedzin wysokiej szansy z 1995 r. był trafny.

Z kolei w 2 na 15 dziedzin przemysłu zaliczonych do tej grupy nastąpił spadek ich produkcji lub stagnacja w ujęciu realnym w stosunku do jej poziomu w Polsce Ludowej. Dotyczyło to przemysłu wyposażenia dla elektrowni (o czym zadecydowała nie tylko likwidacja fabryki turbin w Elblągu, ale także silników elektrycznych i transformatorów najwyższej mocy we Wrocławiu i Łodzi) oraz w przemyśle aparatury pomiarowej, w którym w wyniku decentralizacji powstały liczne małe zakłady, dające wzrost produkcji, ale główne istniejące w nich duże zakłady uległy likwidacji. Gdyby nie to, rozwój we wszystkich tych 15 dziedzinach przemysłu byłby w stanie najbardziej zdynamizować globalny rozwój przemysłu i gospodarki.

2. Drugą charakterystyczną cechą zmian w 15 branżach przemysłu, najbardziej atrakcyjnych dla rozwoju, była znacznie szybsza w nich ekspansja kapitału zagranicznego niż w przemyśle ogółem. Wskazuje na to przede wszystkim wyjątkowo wysoki udział kapitału zagranicznego w prywatyzacji zakładów państwowych, w tych właśnie branżach przemysłu. O ile w przemyśle ogółem zakłady sprywatyzowane z udziałem kapitału zagranicznego stanowiły około 20\% całego potencjału przemysłowego, istniejącego w 1988 r., to w tych 15 branżach łącznie udział ten wyniósł aż 64\%, a więc był ponad 3-krotnie wyższy niż w całym przemyśle. Świadczy to jednoznacznie, że ekspansja kapitału zagranicznego była wyjątkowo silna właśnie w tych branżach.

Można więc mówić o niezwykłej koncentracji ekspansji firm zagranicznych na tych gałęziach przemysłu i szczególnym właśnie nimi ich zainteresowaniu. W tych 15 działach kapitał zagraniczny przejął w wyniku prywatyzacji ponad 50\% całego istniejącego w 1988 r. w nich potencjału przemysłowego. A warto tu przypomnieć, na co wskazuje literatura zagraniczna, że kiedy udział kapitału zagranicznego przekroczy 40\% całego potencjału danego przemysłu, grozi to już bezpośrednią utratą kontroli macierzystego państwa nad tym przemysłem oraz wpływa na zachodzące $\mathrm{w}$ nim realne procesy i podejmowane $\mathrm{w}$ nich decyzje rozwojowe. Stąd udział ten uważa się za górną granicę, której przekroczenie stwarza już pewne niebezpieczeństwa.

Najwyższy był $\mathrm{u}$ nas udział kapitału zagranicznego $\mathrm{w}$ prywatyzacji tego potencjału w następujących branżach przemysłowych, uszeregowanych kolejno: w przemyśle sprzętu telekomunikacyjnego (około 93\%), farb i lakierów (79\%), lotniczym $(74 \%)$, celulozy i papieru $(74 \%)$, samochodowym $(72 \%)$, turbin i wyposażenia dla elektrowni (71\%), sprzętu oświetleniowego (69\%), elektroniki profesjonalnej (55\%).

Tak duża aktywność firm zagranicznych we wskazanych dziedzinach może świadczyć o dobrym rozpoznaniu przez inwestorów zagranicznych sytuacji $\mathrm{w}$ nich 
u nas, czego zabrakło w naszej administracji przemysłowej. Sparaliżowana doktryną neoliberalną nie udzieliła ona zakładom krajowym $\mathrm{w}$ tych dziedzinach ani należytej ochrony przed nieuczciwą konkurencją („un-fair competition”), ani dostatecznego wsparcia w ich rozwoju.

3. Trzecią charakterystyczną cechą przemian w tych dziedzinach przemysłu, ale już wyraźnie dla nas niekorzystna, był wyjątkowo duży w nich również zasięg tzw. „wrogich przejęć” („hostile take-over”), czyli zakupu zakładów nie po to, aby dalej rozwijać ich produkcję, ale wręcz przeciwnie, aby je zamknąć i w ten sposób opanować miejscowy rynek dla towarów własnych, a równocześnie eliminować miejscową konkurencje na tym rynku i w eksporcie. Rozmiary tych „wrogich przejęć” w przemyśle ogółem były u nas prawie 2-krotnie wyższe niż w krajach Europy Zachodniej (23\% u nas wobec $10-15 \%$ średnio w krajach UE).

W niektórych z analizowanych tu branż udział „wrogich przejęć” był wyjątkowo wysoki i osiągną rozmiary nienotowane w innych krajach, w tym nawet zachodnich o orientacji neoliberalnej. Największy był on $\mathrm{u}$ nas $\mathrm{w}$ następujących gałęziach przemysłu uszeregowanych kolejno: przemysł sprzętu telekomunikacyjnego, przemysł komputerowy, turbin i wyposażenia dla elektrowni, przemysł samochodowy (w przeciwieństwie do Czech i Rumunii nie zachowano dotychczasowej krajowej marki wytarzanych samochodów).

Charakterystyczne jest przy tym, że z wymienionych wyżej 4 gałęzi przemysłu aż 3 z nich zaliczają się do „przemysłów wysokiej techniki” i mają kluczowe znaczenie dla modernizacji zakładów przemysłowych wszystkich niemal branż, a są zarazem częścią przemysłu elektronicznego, w którym straty w jego potencjale istniejącym przed 1989 r. były u nas największe.

Dopuszczenie do tego należy uznać za poważny błąd naszej administracji przemysłowej, którego nie może wytłumaczyć nawet ścisłe przestrzeganie zasad neoliberalizmu, graniczące już czasem $\mathrm{z}$ doktrynerstwem, bo umiały tego uniknąć niektóre inne kraje transformacji, jak np. Czechy, Węgry.

Reasumując, to co przedstawiono wyżej pozwala już na podjęcie próby uogólnienia oceny i dokonania pewnego bilansu korzystnych i mniej korzystnych aspektów zmian. Z 15 gałęzi przemysłu objętych tą analizą:

- 7 zostało przejętych przez kapitał zagraniczny,

- 4 uległy likwidacji (gdyż ubytek potencjału istniejącego w nich przed 1989 r. przekraczał 75\%, a wtedy możemy mówić o faktycznej likwidacji),

- tylko w 4 utrzymała się dominacja kapitału krajowego, ale nie był on w stanie zdynamizować ich rozwoju.

W tych analizowanych wyżej 15 gałęziach z reguły zostały zlikwidowane główne zakłady w tych branżach. Przykładem tego mogą być w elektronice profesjonalnej - zakłady w Piasecznie i Warszawie, w przemyśle sprzętu telekomunikacyjnego - trzy zakłady należące do największych w Europie, a mianowicie w Radomiu, Bydgoszczy i Warszawie, w przemyśle wyposażenia dla elektrowni - w Elblaggu, Łodzi i Wrocławiu, w przemyśle komputerowym 
- we Wrocławiu i Błoniu, a w przemyśle sprzętu oświetleniowego - w Pile i w Warszawie.

Wprawdzie na ich miejscu często powstawały liczne małe zakłady prywatne i rozwijano indywidualną działalność produkcyjną pracowników byłych zakładów zlikwidowanych, czemu towarzyszyło powstawanie różnych form przemysłu garażowego "cottage industry”. Nie zmienia tej oceny nawet fakt, gdy pozostały z nich jakieś resztki, po poprzednio istniejącym potencjale przemysłowym.

Ich pozycja na rynku jest bowiem wielokrotnie słabsza niż zakładów dużych. Są one mniej odporne na zmiany koniunktury, słabsza jest w nich $\mathrm{z}$ reguły orientacja proeksportowa, ale przede wszystkim nie odgrywają one większej roli z powodu słabości ich zaplecza $\mathrm{B}+\mathrm{R}-\mathrm{w}$ procesach innowacyjnych i modernizacji struktur przemysłowych, a zdolność do innowacji w ostatecznym rezultacie zadecyduje o przyszłości w Polsce.

Wpłynęło to na powstanie w Polsce struktury niekorzystnej i niesprzyjającej procesom innowacyjnym w przemyśle i gospodarce. Znajduje to wyraz w niższym u nas udziale w całej produkcji przemysłowej niż w innych krajach tych dziedzin przemysłu, które w największym stopniu wchłaniają i generują innowacje. Dotyczy to zwłaszcza „przemysłów wysokiej techniki”. Rezultatem tego jest niedorozwój u nas przemysłu elektronicznego, komputerowego, precyzyjnego, biotechnologii i chemii specjalizowanej.

Jak więc w sumie oceniać te zmiany? Sam ich kierunek na zwiększenie udziału kapitału zagranicznego w przemyśle w Polsce był słuszny i zgodny z założeniem przyjętym u progu transformacji. Stanowiło to bowiem warunek stworzenia w Polsce gospodarki rynkowej, co bez otwarcia naszej gospodarki na rynek światowy i konkurencję zagraniczną byłoby wręcz niemożliwe. Równocześnie stwarzało to szansę na przejście do nowoczesnego modelu rozwoju, który charakteryzuje się dziś na całym świecie szerokim otwarciem dla inwestycji zagranicznych w różnych dziedzinach przemysłu krajowego. Ale równocześnie niepodważalnym faktem jest, że:

- zasięg przejęcia tych dziedzin przemysłu przez kapitał zagraniczny okazał się znacznie większy niż się tego spodziewano i przewidywano u progu transformacji, i co wyraźnie zaskoczyło krajowych decydentów i autorów tej koncepcji,

- udział kapitału zagranicznego w przemyśle w Polsce należy obecnie do najwyższych w Europie, poza małym krajami, jak Litwa, Łotwa czy Estonia,

- udział ten jest już bardzo bliski granicy $40 \%$, a więc wspomnianego wyżej poziomu, którego przekroczenie stwarza bezpośrednie zagrożenie utratą wpływu przez państwo macierzyste na procesy rozwojowe $\mathrm{w}$ tych dziedzinach,

- $\quad$ w gałęziach opanowanych przez firmy zagraniczne następstwem tego był z reguły jakościowy wzrost cen wyrobów wytwarzanych w tych branżach w stosunku do ich poziomu w zakładach krajowych, a to oznaczało jakościowy wzrost wydatków na zakup tych wyrobów finansowany przez budżet państwa i dodatkowo obciążyło budżety rodzin, a więc całe społeczeństwo (patrz np. leki).

Tak radykalne zmiany w tym okresie umożliwiły z drugiej strony osiągnięcie przełomów technologicznych w szeregu dziedzin przemysłu i gospodarki na skalę trudno wyobrażalną $\mathrm{u}$ progu transformacji, co oznaczało $\mathrm{w}$ rezultacie przełom $\mathrm{w}$ poziomie cywilizacyjnym 
naszego społeczeństwa (informatyzacja, telekomunikacja, motoryzacja itp.). Dlatego szereg niekorzystnych zjawisk i niepowodzeń można w jakimś stopniu uznać za cenę uzyskanego w tym okresie postępu i niepodważalnych osiągnięć.

Z kolei, jak w sumie oceniać perspektywy tych dziedzin przemysłu na przyszłość? Likwidacja poszczególnych zakładów powodowała z reguły daleko idącą destrukcję potencjału przemysłowego w całej danej branży, a także istniejących w nich powiązań kooperacyjnych i struktur produkcji, a często także odpływ kadr kierowniczych, nierzadko zagranicę, z małą już szansą na ich powrót do kraju. Przykładem mogą tu być polscy elektronicy, którzy po emigracji budowali od podstaw przemysł elektroniczny w Norwegii. Dlatego odbudowa ekspansji kapitału krajowego w tych dziedzinach wydaje się dziś już mało prawdopodobna, jeżeli nie wręcz niemożliwa.

W tych warunkach nasza główna uwaga musi być obecnie skierowana na nowe obszary i dziedziny przemysłu, w których możemy mieć szanse skutecznego konkurowania. A taki proces przebiega intensywnie już obecnie i na dużą skalę w wyniku relatywnie dużej aktywności i przedsiębiorczości polskiego biznesu. Przyszłe gałęzie przemysłu wysokiej szansy będą więc z pewnością istotnie różniły się od tych, które oceniano jako takie w latach 80. i 90. ubiegłego stulecia. Ale tym bardziej uruchomienie odpowiednich badań do ich zidentyfikowania staje się dziś najpilniejszym zadaniem.

W rezultacie przedstawionych wyżej przemian nastąpiła całkowita zmiana struktury własnościowej przemysłu w Polsce. W przeważającej jego części, zwłaszcza w tych zaliczonych do grupy 15 gałęzi przemysłowych najbardziej atrakcyjnych z punku widzenia procesu rozwoju, przemysł w naszym kraju stał się w dużej mierze już „przemysłem filialnym”, czyli takim, w którym decydującą rolę odgrywają filie koncernów zagranicznych, które weszły na nasz rynek, a nie kapitał krajowy.

Zbyt radykalne przemiany w tym kierunku nie musiały być jednak tak głębokie, gdyby już na progu transformacji dziedziny najbardziej atrakcyjne dla rozwoju objęto silną ochroną i kontrolą zachodzących w nich procesów prywatyzacji przemysłu, a na tej podstawie stworzono przemyślaną nowoczesną sektorową politykę przemysłową ściśle zintegrowaną z polityką przekształceń własnościowych, której praktycznie w ogóle nie było. W rezultacie ich kierunki często się rozbiegały w odmienne strony. Świadczyć o tym może kompletny krach Narodowych Funduszów Inwestycyjnych w przemyśle, chyba, że ich ukrytą intencją było przyspieszenie likwidacji przemysłu państwowego.

Nowe elementy w dotychczasowych diagnozach dotyczą zwłaszcza społecznych aspektów likwidacji wielu zakładów. W ich ramach usiłuje się odpowiedzieć na pytanie: „Jakie były społeczne skutki likwidacji zakładów lub konkretnych gałęzi przemysłu na danym terenie?" A odpowiedź na to pytanie ma szczególne znaczenie właśnie dla województw i miast przemysłowych, które ponoszą główny tego ciężar. W sumie dotyczyło to prawie 2 mln osób, które utraciły swe miejsca pracy w zlikwidowanych zakładach.

Przykładem analizy z tego punktu widzenia może być książka Katarzyny Dudy, która opiera się na sytuacji w Wałbrzychü ${ }^{4}$ W dyskusji na ten temat stwierdzono, że: „w życiu

\footnotetext{
${ }^{4}$ K. Duda, Kiedyś tu było życie - teraz jest tylko bieda, Książka i Prasa, Warszawa 2019.
} 
wielu ludzi najważniejszą zmianą był upadek ich fabryk" ${ }^{\prime 5}$. Największe problemy z tego powodu występowały w miejscowościach, w których istniała tylko jedna większa fabryka, stanowiąca podstawę egzystencji tej lokalnej społeczności, a uległa likwidacji po 1989 r. Dla nich likwidacja ta była jednoznaczna ze zniknięciem jedynego źródła utrzymania. A takich miejscowości nawet na Mazowszu było niemało. Dlatego zwiększenie aktywności władz lokalnych w tej dziedzinie, wprawdzie nie może wyeliminować tych likwidacji, może jednak odczuwalnie zmniejszyć ich ujemne następstwa społeczne.

\section{Najbardziej atrakcyjne dziedziny przemysłu dla rozwoju na terenie Warszawy i województwa mazowieckiego}

Aby dokonać wyboru obszarów przemysłu spełniających w najwyższym stopniu kryterium „największej szansy” trzeba sobie najpierw odpowiedzieć na pytanie: „Dlaczego w ogóle dokonanie takiego wyboru jest niezbędne, a jego zaniechanie może przynieść konkretne straty i ujemne zjawiska społeczne?" Dotyczy to każdego terenu, zarówno państwa jako całości, jak i województw czy miast o znaczącym potencjale przemysłowym.

Otóż pomiędzy losami poszczególnych zakładów przemysłowych a konkretnych ludzi, zachodzą wyraźne analogie i podobieństwa. Zakłady przemysłowe powstaja przechodzą okres dojrzewania, osiągają szczytowy poziom swych możliwości produkcyjnych, wchodzą w okres zmniejszania się ich znaczenia i zanikania, a w końcu nieuchronnie kończą swe istnienie. Dlatego ten ostatni etap zyskał nazwę "przemysłów o spadającym znaczeniu” („declining industries”). Okres ten można i trzeba wcześniej przewidzieć. Dobry gospodarz w każdym województwie, regionie czy w miastach przemysłowych musi sobie odpowiedzieć na pytanie: „Jakie tradycyjne gałęzie przemysłu na jego terenie mogą zamknąć się w ciągu najbliższych 10-15 lat i czy istnieje nowy przemysłowy potencjał, który może wypełnić lukę spowodowaną upadkiem przemysłu tradycyjnego?" A to wymaga analizy struktury przemysłu istniejącego na danym terenie z tego punktu widzenia. Niestety, ta świadomość jest u nas w praktyce bardzo uboga i niedostateczna. Wymaga to bowiem znacznie dłuższego spojrzenia w przyszłość niż 5-letni cykl wyborów do kolejnych sejmików czy rad miejskich. Brak takiego dłuższego spojrzenia występuje u nas zbyt powszechnie. Postawy tego rodzaju („shorttermism”) spotykają się z coraz większą krytyką nawet w krajach o orientacji neoliberalnej. Istotną tego przyczyną jest sztuczne ograniczenie uwagi lokalnych władz samorządowych, głównie czy tylko do sektora samorządowego na danym terenie.

Do skutecznego zarządzania w dzisiejszych warunkach potrzebne jest spojrzenie na gospodarkę z dłuższej perspektywy („longtermism”) nawet w skali województw i większych miast. Dlatego konieczne jest w związku z tym zapewnienie władzom lokalnym szerszego

${ }^{5}$ Gdy stracili pracę, skończyło się wszystko, wywiad Jakuba Dymka z Katarzyną Dudą, Tygodnik „Przegląd" z 24 czerwca 2019 r., s. 17. 
spojrzenia na całą gospodarkę województwa czy miasta niż tylko sektor samorządowy. A to wymaga bardziej kompleksowego spojrzenia na gospodarkę łącznie z biznesem prywatnym, podmiotami zarządzanymi centralnie i sektorem samorządowym. Brak tego stanowi często główną słabość i jedną z przyczyn niepowodzeń i opóźnień w modernizacji struktury przemysłu w poszczególnych województwach i miastach.

Przed próbą rozpoznania, jakie dziedziny przemysłu mogą mieć szanse rozwoju na terenie Mazowsza, trzeba jeszcze przedstawić dodatkowo warunki jakie powinny spełniać te nowe zakłady i branże oraz ich cechy, aby zasługiwały one na aktywne wsparcie i promocję ze strony władz lokalnych. Wśród tych cech trzeba uwzględnić co najmniej cztery, a mianowicie:

- $\quad$ największe szanse miałyby te zakłady, które należą do dziedzin, leżących w polu zainteresowania Unii Europejskiej ich rozwojem, a stąd mogą one liczyć na preferencję z tej strony, a zwłaszcza na:

- wsparcie w finansowaniu z funduszów unijnych,

- $\quad$ stopniowe łagodzenie w stosunku do nich sankcji przewidzianych dla „pomocy publicznej („public aid”),

- te, które mogą umożliwić maksymalne wykorzystanie potencjału uczelni zlokalizowanych na danym terenie i działających na nim instytucji naukowych i ośrodków B+R,

- spełniają wymogi „neutralności ekologicznej”, czyli wzrost emisji w pełni równoważy zmniejszenie dotychczasowego zanieczyszczenia środowiska,

- mają szanse na uzyskanie jak najszerszego poparcia społecznego dla nich ze stronymiejscowych środowisk, nie tylko biznesu i administracji lokalnej, ale także hobbystów różnego rodzaju, organizacji pozarządowych, a więc pobudzić lokalne poczucie partnerstwa biznesowego („local business partnership”).

Na terenie Mazowsza wymogi te mogłyby spełnić najlepiej te branże przemysłu, które byłyby w stanie odegrać rolę nowego czynnika napędowego i sprawczego w procesie rozwoju, a mianowicie powodujące:

- $\quad$ najwyższy wzrost popytu i zapotrzebowania na wyroby i usługi wytwarzane w tych gałęziach przemysłu, co najmniej 2-krotnie wyższy niż wzrost popytu na wyroby przemysłowe ogółem, co może dynamizować cały przemysł na danym terenie,

- maksymalne wykorzystanie potencjału naukowego i wdrożeniowego istniejącego na Mazowszu, szczególnie silnie rozwiniętego tu na tle kraju,

- maksymalne wykorzystanie terenów poprzemysłowych, wyposażonych w infrastrukturę przemysłowa, po zlikwidowanych zakładach, których zasoby tu na Mazowszu są największe w skali kraju,

- nawiązanie do tradycji rozwoju danej branży lub w branżach do nich zbliżonych i technologiach na tym terenie,

- możliwości wejścia w kooperację ponadgraniczną („,crossborder cooperation”) z krajami o zaawansowanym rozwoju tych dziedzin przemysłu.

W świetle przedstawionych wyżej kryteriów największe szanse na powstanie nowych dziedzin przemysłu na terenie Mazowsza wydaje się mieć 12 następujących branż: 
1. Przemysł elektroniczny i komputerowy, wchodzące obecnie w okres masowego przestawienia na nową generację techniki i stosowanych w nich technologii, a równocześnie przezbrojenia przemysłu na technologie cyfrowe, w rozwoju których odgrywają one rolę decydującą. Przełomowe znaczenie z tego punktu widzenia będzie miało zwłaszcza wykorzystanie i zastosowanie w skali masowej „sztucznej inteligencji”. Powoduje to, że zakłady przemysłowe zdolne do uczestniczenia $\mathrm{w}$ tym procesie będą miały zapewnioną perspektywę wyjątkowo wysokiego - najwyższego w całym przemyśle - tempa wzrostu zapotrzebowania na wytwarzane w nich wyroby w ciągu całego okresu do roku 2035, a więc w ciągu najbliższych 15 lat.

Najwyższy wzrost popytu na te wyroby wystąpi w przypadku:

- sprzętu nowej generacji dla Internetu i elektroniki profesjonalnej,

- wyposażenia elektronicznego dla nanotechnologii,

- elementów elektronicznych dla robotów przemysłowych i usługowych.

Aktywny rozwój tych dziedzin stałby się wielką szansę dla Mazowsza, a za taką lokalizacją przemawiają korzystniejsze niż w innych regionach kraju warunki, tj.:

- tradycje w rozwoju na tym terenie,

- wyjątkowo wysokie zasoby niewykorzystanej powierzchni poprzemysłowej, uzbrojonej w infrastrukturę przemysłowa, ponieważ zakres likwidacji zakładów na tym terenie był największy w kraju (Tarchomin, Wola, Służewiec, Praga itp.),

- dostęp do największej w kraju koncentracji uczelni wyższych i instytucji naukowych, jak również ośrodków B+R.

W sumie Mazowsze ma dla rozwoju tych dziedzin przemysłu korzystniejsze warunki, poza woj. małopolskim (Kraków) i dolnośląskim (Wrocław). Przemawia to zwłaszcza za odbudową elektroniki na Mazowszu, która poniosła tu największe straty. Szczególnie interesujące, $\mathrm{z}$ tego punktu widzenia, mogą być dla nas doświadczenia Irlandii, to jest umiejętne wykorzystanie współpracy ze światowymi koncernami.

2. Przemysł ekologiczny. Wytwarza on najszerszą gamę sprzętu, materiałów stosowanych w ochronie środowiska i klimatu, narzędzia niezbędne do kontroli i monitoringu oraz tzw. „czyste technologie”, zmniejszające zagrożenia dla środowiska. Jest to przemysł o największych szansach rozwojowych. Uznaje się go dziś za główny sektor wzrostu w przemyśle XXI w. W ciągu najbliższych 10 lat popyt rynku światowego na te wyroby ma zwiększyć się 1,5-2-krotnie, a więc ponad 10\% średniorocznie.

Mazowsze nie ma szerszych doświadczeń w tym przemyśle. Największe szanse, wydaje się, mogłaby mieć na tym terenie produkcja sprzętu do monitoringu środowiska, gdzie prace badawcze osiągnęły tu najszerszy zasięg. Występowanie tej gałęzi w strukturze przemysłu na danym terenie stwarza szansę na zdynamizowanie rozwoju całej produkcji przemysłowej. Stąd jego rozwój na terenie Mazowsza zasługuje na szczególną uwage i poparcie, także ze strony władz lokalnych. Szanse te wzrosłyby w zasadniczy sposób, gdyby udało się wejść w kooperację w rozwoju tego przemysłu z przemysłem niemieckim, przodującym w tej dziedzinie. 
3. Przemysł sprzętu dla energetyki odnawialnej. $W$ tym przemyśle przewiduje się w skali rynku światowego w ciągu najbliższych 5 lat wzrost popytu o 30\% rocznie, a w następnym pięcioleciu nie mniej niż o $20 \%$ rocznie. Tak wysokie tempo jego rozwoju przemawia za podjęciem ryzyka związanego z tym przemysłem. Jeżeli uwzględnić duże tradycje Mazowsza w rozwoju przemysłu elektrotechnicznego wydaje się, że największe szanse miałaby produkcja sprzętu dla energetyki opartej na wykorzystaniu energii słonecznej (baterie i kolektory słoneczne oraz urządzenia fotogalwaniczne).

4. Przemysł farmaceutyczny. Przemysł ten stoi obecnie w obliczu konieczności przestawienia na produkcję środków nowej generacji, które będą stosowane w terapii genowej, która osiągnie masową skalę. Równocześnie w zasadniczy sposób wzrośnie produkcja środków produkcji stosowanej w profilaktyce zdrowotnej i w badaniach przesiewowych. Ich udział ma bowiem wzrosnąć od 1/3 aż do 40\% całych wydatków na ochronę zdrowia. Jeszcze większe perspektywy rozwoju może stworzyć wykorzystanie leków onkologicznych pochodzenia biotechnologicznego.

Za rozwojem tego przemysłu na Mazowszu przemawiają duże tradycje jego rozwoju na tym terenie, bogate zasoby uzbrojonej powierzchni poprzemysłowej w Warszawie (Tarchomin i kilka lokalizacji na Woli). Największe szanse miałaby produkcja generyków, czyli leków nie chronionych patentami, gdyż ich produkcja w kraju może być znacznie tańsza od importu, co pozwoliłoby zmniejszyć obciążenie budżetu naszego państwa skokowo rosnącymi wydatkami na ten cel.

5. Przemysł chemii specjalizowanej („,special chemicals”). Wytwarza się w nim preparaty dostosowane do specyficznych potrzeb poszczególnych gałęzi przemysłu i odbiorców. W przyszłości będzie możliwe w coraz szerszej skali - dzięki informatyzacji przemysłu - dostosowanie produkcji do jednostkowych potrzeb konsumentów, określanej terminem customizacji („customization”). A popyt na te wyroby jest wyjątkowo zróżnicowany i inny w każdej niemal gałęzi i dziedzinie. Stwarza to duże możliwości specjalizacji przemysłu lokalnego w produkcji określonego typu i rodzaju tych wyrobów.

6. Przemysł biotechnologii. Przeżywa on obecnie okres swego największego dotychczas rozwoju, a więc swoisty „boom”, a projektowanie i wytwarzanie preparatów biotechnologicznych („,bioengineering”) staje się dziś nową gałęzią i rodzajem przemysłu. Szanse z nią związane mogłyby wzrosnąć wręcz skokowo, gdyby sprawdziły się obecne prognozy przewidujące przełom w wykorzystaniu tych form dla terapii onkologicznej. Przemysł ten w największym stopniu związany jest i zależy od zaplecza badawczo-rozwojowego i wyższych uczelni, które właśnie w tym regionie są najsilniej rozwinięte.

7. Przemysł optyczny. Największy w nim wzrost popytu dotyczy przyrządów laserowych, coraz szerzej stosowanych nie tylko w przemyśle. Za rozwojem tej dziedziny na Mazowszu przemawiają dość zaawansowane tu badania nad techniką laserową oraz istnienie terenów poprzemysłowych (m.in. w Warszawie na Pradze i Centrum Optyki).

8. Przemysł techniki jądrowej. Produkuje on preparaty izotopowe coraz szerzej wykorzystywane w medycynie, nauce, przemyśle i ochronie środowiska. Coraz szerzej stosowane są też w diagnostyce medycznej, zwłaszcza w onkologii. Za rozwojem tego przemy- 
słu na Mazowszu, poza wysoką dynamiką popytu, przemawia fakt, że jest ono niemal monopolistą w tej produkcji w kraju (ośrodek w Świerku koło Warszawy) i jesteśmy jednym z największych producentów w tej dziedzinie w Europie).

9. Przemysł wytwarzający samochody elektryczne i hybrydowe. Świat stanął w obliczu konieczności przestawienia samochodów na napęd niegrożący szkodliwą dla ludzi emisją dwutlenku węgla, a jeszcze bardziej niebezpiecznych gazów powstających przy uruchamianiu wałów hamulcowych. Jedyną alternatywą do wzrostu produkcji o nowych napędach byłoby całkowite zamrożenie stanu samochodów na obecnym poziomie i wprowadzenie drastycznych restrykcji w tej dziedzinie. Wzrost produkcji samochodów o nowych napędach jest nieuchronny. Warszawa ma tradycje i duże obszary poprzemysłowe uzbrojone w infrastrukturę przemysłową po FSO na Żeraniu. Ale nie wiadomo jeszcze czy udałoby się stworzyć ośrodek zdolny do projektowania i generowania samochodów o nowym napędzie, chociaż nawet sam tylko montaż tych samochodów byłby bardzo atrakcyjny.

10. Przemysł kosmiczny. Rozwija się on obecnie tak szybko, że stwarza możliwości rozwoju produkcji sprzętu do wyposażenia rakiet i eksploatacji obiektów kosmicznych poza ziemią także dla krajów średnich, a nawet i mniejszych. Za rozwojem tego przemysłu na Mazowszu, które nie ma w tej dziedzinie większych tradycji rozwoju, przemawia fakt, że przemysł ten jest nośnikiem najbardziej nowoczesnych technologii, których brak może odbić się na poziomie technologicznym całego przemysłu w danym regionie. Ale w przypadku uruchomienia tego przemysłu na Mazowszu wymagałoby to ścisłej współpracy z Wrocławiem i Białymstokiem, które są najbardziej zaawansowane w rozwoju tej produkcji.

11. Przemysł aparatury medycznej i sprzętu medycznego. W przemyśle tym przewiduje się największy wzrost popytu w związku z procesem cyfryzacji ochrony zdrowia na skalę nigdy dotąd niewystępująca, czyli zastosowaniem technologii cyfrowej w medycynie. W rezultacie uważa się, że będzie to jedna z najbardziej dynamicznie rozwijających się gałęzi przemysłu w XXI w. W ciągu najbliższych 20 lat nastąpić ma skokowy wzrost zapotrzebowania na te wyroby. Dotyczy to zwłaszcza sprzętu dla diagnostyki i profilaktyki, gdzie przełom będzie największy. Wymagać to będzie ogromnego wzrostu wydatków na sfinansowanie zakupu tego sprzętu, który w większości krajów finansowany jest z budżetów państw i samorządów.

12. Produkcja wyrobów służących realizacji funkcji metropolitarnych Warszawy jako stolicy, zwłaszcza w sprzęcie informacyjnym i agencjach informacyjnych.

W tych 12 dziedzinach przemysłu możliwości podejmowania nowej innowacyjnej produkcji na Mazowszu wydają się większe niż na pozostałym obszarze kraju („starts-up”). Reasumując uważam, że gdyby władze Mazowsza zdecydowały się na wsparcie i promocję nowych branż na swoim terenie, to powinny w pierwszej kolejności skoncentrować się właśnie na tych 12 wyżej wymienionych. Pomoc dla nowo powstających firm w tych dziedzinach może bowiem dać największe „efekty zewnętrzne” i prorozwojowe. Z tego względu ma to pełne uzasadnienie ekonomiczne. 
Obok opisanej „dwunastki” Mazowsze ma również korzystniejsze niż inne regiony warunki do rozwoju przemysłu wytwarzającego materiały i sprzęt stosowany w nowoczesnej edukacji w związku z umasowieniem podręczników informatycznych, masowej skali produkcji e-booków, a także gier komputerowych czy też w produkcji sprzętu dla przemysłu rozrywkowego. Ale stan rozpoznania tych możliwości nie jest jeszcze dostateczny do bardziej szczegółowego zarysowania szans ich rozwoju.

Mazowsze ma także duże tradycje w przemyśle zbrojeniowym. Jednakże obecnie na świecie dominuje raczej tendencja do unikania lokalizacji obiektów tego przemysłu w stolicach krajów i metropoliach, aby nie stwarzać dla nich dodatkowego zagrożenia. Ale także i tu istniałyby pewne szanse, gdyby udało się wejść w kooperację w tym przemyśle np. z Izraelem, przodującym w tej dziedzinie.

W sumie można postawić tezę, że należałoby dążyć do tego, aby udział tych dziedzin przemysłu, który obecnie szacuje się w województwie mazowieckim na 8-10\% całego zatrudnienia w przemyśle na tym obszarze ${ }^{6}$, zwiększyć zasadniczo w latach 2020-2035 do co najmniej 20\%, a w dalszej perspektywie nawet do 1/3 lub 40\%. Mazowsze ma bowiem do rozwoju tych gałęzi najlepsze i najkorzystniejsze warunki w skali kraju i tę szansę należy, wydaje się, maksymalnie wykorzystać.

Rozwojowi tych dziedzin przemysłu, najcenniejszych z punku widzenia potrzeb przyszłego rozwoju, mogłoby sprzyjać dodatkowo wzmożenie działania i aktywności władz lokalnych Warszawy i województwa. Poza wszelką dyskusją jest teza, że Warszawie potrzebna jest większa aktywność władz państwowych i samorządowych do pobudzenia rozwoju przemysłu najbardziej nowoczesnego, który mógłby zastąpić lukę powstającą w miarę zaniku przemysłu tradycyjnego na tym terenie. Sprzyjać temu mogłyby takie działania jak:

- podjęcie własnej polityki promocji w stosunku do dziedzin pożądanych na tym terenie, modernizujących jego strukturę, niezależnej i wzbogacającej politykęcentralną. Powinna być ona realizowana przez:

- ułatwienia dostępu do terenów poprzemysłowych,

- obniżenie podatków i świadczeń lokalnych,

- utworzenie Sztabu dla Reindustrializacji Regionu, łączącego przedstawicieli administracji centralnej i lokalnej z przedstawicielami biznesu, nauki, organizacji pozarządowych, nawet hobbystów różnego rodzaju, co dałoby stworzenie klimatu dla lokalnego partnerstwa biznesowego („business local partnership”),

- $\quad$ wykorzystanie możliwości nawiązywania współpracy ponadgranicznej z partnerami bardziej zaawansowanymi w rozwoju „przemysłów największej szansy”.

Reasumując dotychczasowe rozważania, można je zakończyć sformułowaniem jednego podstawowego wniosku. Dotyczy on nie tylko całego naszego kraju, ale także każdego regionu czy nawet miasta. Może być on uznany za główne przesłanie, płynące z powyższej pracy.

\footnotetext{
${ }^{6}$ Trendy zmian w poziomie i strukturze zatrudnienia w województwie mazowieckim w latach 1999-2008, Trendy Rozwojowe Mazowsza, 2, Mazowieckie Biuro Planowania Regionalnego, Warszawa 2012, s. 79-91.
} 
Podstawową przyczyną większości stwierdzonych w przedstawionym opracowaniu niedomagań i nieprawidłowości w naszej gospodarce jest zbyt krótki, a z reguły niedostateczny horyzont oceny skutków zachodzących w niej procesów i zmian oraz wynikających z nich problemów. Znajduje to wyraz we wspomnianej wyżej zbyt krótkiej perspektywie patrzenia na gospodarkę, co w całej pełni dotyczy również województw i miast, odgrywających kluczową rolę w ich rozwoju.

Wydaje się, że w naszej gospodarce zjawisko to wystąpiło z wyjątkowym nasileniem i powoduje szczególnie szkodliwe konsekwencje.

Jeżeli lektura niniejszego opracowania skłoni do zwrócenia większej uwagi na te aspekty naszego rozwoju, będą uważał jego cel za spełniony. 


\section{Former and present attractiveness of industrial sectors in the development process of the country and Mazovia}

\section{ABSTRACT}

In the current discussions on the past and future prospects of the industry in our country, at least four areas require, in my opinion, much more attention and reflection. This means learning from our not always only positive - experiences.

Four matters are the most pressing, and I believe that getting answers to the following four questions is of the utmost urgency:

1. What measures to stimulate development, what we sometimes call the ,anatomy of growth or development', were applied to the industry in Poland in the initial period of its transformation and during the first 25 years - 1990-2014. Among others, what factors initiated the development, propelled it and contributed conclusively to its further growth, and whether and what changes are currently required?

2. If the state decides to support the development of selected branches and areas of industry that offer the greatest development opportunities - what should be the criteria for their selection and whether they require addenda or corrections?

3. What changes were made in these industries which were recognized as having the greatest development opportunities in the initial period of the abovementioned Polish transformation? What conclusions should be drawn from the changes currently taking place in them?

4. Which branches of industry are and may be the most attractive for development in Warsaw and Mazovia region?

In each of these four areas, there have recently been many new addenda to the existing diagnoses and proposals which seem to be worthy of discussion.

Key words: industry, development, transformation process in industry, attractive industries for Warsaw and the Mazovia region

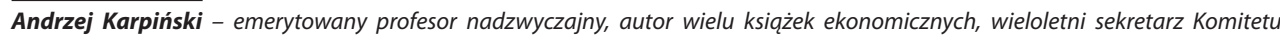
Prognoz Polskiej Akademii Nauk „Polska 2000 Plus”.

Andrzej Karpiński - retired associate professor, author of many economic books, long-term secretary of the Forecast Committee of the Polish Academy of Sciences "Polska 2000 Plus". 